\section{Potential of ecotourism as a mechanism to buoy community livelihoods: the case of Musina Municipality, Limpopo, South Africa}

\author{
Azwindini Isaac Ramaano \\ Department of Geography and Geo-Information Sciences, \\ School of Environmental Sciences, University of Venda, Thohoyandou, South Africa
}

Mechanism to buoy community livelihoods

Received 18 February 2021 Revised 15 March 2021 16 March 2021 29 March 2021 Accepted 29 March 2021

\begin{abstract}
Purpose - This study evaluates prospects of using ecotourism industry to advance community livelihoods in Musina Municipality, Limpopo, South Africa.

Design/methodology/approach - Using questionnaire surveys, interviews primarily, supplemented by focus group discussions and interviews, primary data has been collected reflective of the potentiality of ecotouristic activities in Musina Municipality. To a lesser extent, field observations contribute to these primary sources. Extra insights are obtained through documentary reviews (secondary sources). Data is analyzed using quantitative statistical techniques supplemented by qualitative approaches.

Findings - The study confirmed substantial ecotourism potential of the Musina Municipality and that this potential is manifest irrespective of geographic and demographic factors. However, the study reports a low current ecotourism impact in the Musina Municipality with consequential minimal benefits accruing to the enhancement of the standard of living in the local community. An inference is made that the key gap area impeding the realization of ecotourism potential in the Musina Municipality is the absence of a well-articulated tourism strategy linked to the sustainable economic development of the communities involved. Several fruitful initiatives for ecotourism consonant with local factor endowments are proposed.

Originality/value - Although, taken in topical isolation, matters of community livelihoods and sustainable development have been increasingly coming to the forefront of research on tourism, few studies have taken a holistic approach predicated on the integration of community livelihood and sustainable development roles of various forms of ecotourism in community development within many rural areas. This study represents the first case study employing an integrated approach to analyze ecotouristic potential of rural Musina Municipality, one of the driest areas in the far North of Limpopo Province, South Africa, characterized by low standard of living juxtaposed with high touristic potential.
\end{abstract}

Keywords Tourism, Socioeconomic development, Sustainable tourism development, Ecotourism, Agro-tourism, Heritage tourism, Community-based natural resource management, Poverty alleviation and sustainability

Paper type Case study

\section{Introduction}

With limited access to basic amenities such as educational services and employment opportunities, rural communities often lag behind in terms of standard of living relative to their urban community counterparts in any given developing country. Rural communities in the Musina Municipality, South Africa - no differently - are characterized by such

(C) Azwindini Isaac Ramaano. Published in Journal of Business and Socio-economic Development. Published by Emerald Publishing Limited. This article is published under the Creative Commons Attribution (CC BY 4.0) licence. Anyone may reproduce, distribute, translate and create derivative works of this article (for both commercial and non-commercial purposes), subject to full attribution to the original publication and authors. The full terms of this licence may be seen at http://creativecommons.org/licences/by/4.0/legalcode

The author thanks SANSA Earth Observation for sponsoring this investigation.

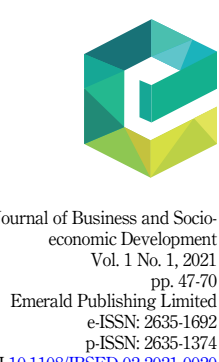

DOI 10.1108/JBSED-02-2021-0020 
JBSED

1,1

marginalization (May, 1998; Shackleton et al., 2007; Ramaano, 2019). Thus, although South Africa, on the national level, constitutes as an upper-middle-income country in terms of the global income-per-capita pecking order, that high national ranking belies a maldistribution of income within the country. To level urban-rural discontinuities, eradicating rural poverty is critical (De Haan, 1999; Kirsten and Rogerson, 2002). Given these stark economic discontinuities, national and provincial governments have elevated improvement in rural standard of living as an economic priority in South Africa (Kirsten and Rogerson, 2002; Ramaano, 2019). To that end, the Integrated Sustainable Rural Development Strategy (ISRDS) was inaugurated to counter rising poverty and unemployment. The ISRDS sought to tap into the potential of rural areas beneficial particularly through the cultivation of entrepreneurship (South Africa, 2000). An important sector earmarked for rural development in the ISRDS is tourism industry [1] with tourism investment being viewed as a mechanism to empower marginalized populations falling under the rubric of previously disadvantaged individuals (PDIs) (Kirsten and Rogerson, 2002; Ramaano, 2019). The Musina rural communities are in urgent need of such investments to promote socioeconomic improvement and engender income sustainability (South Africa, 1996; Ramaano, 2019). However, the private sectors, baulking at supplying the level of investment in touristic enterprises needed, has evinced reticence to advance tourism in the rural areas of South Africa. Complexity and uncertainty regarding land ownership, poor infrastructure support, lack of an existing tourism market and risk aversion among financial institutions constitute the litany of factors driving this reticence (Kirsten and Rogerson, 2002).

\subsection{Sustainable ecotourism as a fillip for boosting livelihoods}

Sustainable ecotourism, as a trend in tourism development, evinces a discernible global trend (Ferreira, 2004; UNEP, 2016). Promoted as one of the fundamental routes of socioeconomic advancement, sustainable ecotourism has found a niche in the national development models of numerous countries (Liu et al., 2012; Ekanyake and Long, 2012; Nheta, 2017). Other sustainable activities complement ecotourism [2]. Sustainable ecotourism revolving around nature reserves and parks can boost the livelihoods of local communities living in and around these protected areas. In rural areas, the link between tourism and national development strategies designed to benefits the targeted beneficiaries is manifest (Banskota and Sherma, 1996; Scheyvens, 1999). To be effective in the capacity amelioration of rural livelihoods, however, tourism development ought to be designed to spur rural job creation and income generation targeted to the touristic potential of a particular rural community (Ashley et al., 2000; Ashley, 2002; Goodwin, 2002; Ryan and Page, 2012). Gains emanating from such targeted developments in tourism with respect to indigenous communities dwelling around the protected areas have been noted by Chok et al. (2007), Scheyvens (2007), Zhao and Ritchie (2007), Jamal and Stronza (2009) as well as Mitchell and Ashley (2010). In all these studies, a common observation manifests: rural employment, capacity building in enterprise development and management, advancement in social welfare and revenue creation stem from well-planned investment in rural enterprises in the touristic sector with concomitant increases in rural livelihoods (Spenceley, 2008; Mitchell and Ashley, 2010; Mugizi et al., 2017). However, such good planning necessitates that conservation area directors and ecotourism entrepreneurs coordinate and have access to essential information with respect to: the ecotouristic potential and factor endowments of any particular rural community as well to all concerned stakeholders integral to, or interacting with, the particular community, be they local inhabitants spanning or prospective tourists (Eagles and McCool, 2002; Ferreira, 2004). In the sampled villages within the Municipality, Big 
Tree Nature Reserve and Nwanedi Nature Reserve and Resort stand out as prominent potentially sustainable ecotouristic activities (Plates 1 and 2). The Musina Municipality is characterized by biodiversity such that sustainable economic potential of ecotourism (along with other sustainable tourism in the form of, e.g. cultural tourism) can be resourced in a way consonant with advancing community livelihood if planned and executed effectively (Ramaano, 2019). Regrettably, however, ecotourism potential often is suboptimally exploited such that the promised sustainability fails to manifest leaving local communities in situations of continued economic vulnerability. In the foreground of the juxtaposition of the high potential for - yet currently meager returns actually accruing to - community livelihood derived from ecotourism, the prospects of using the sustainable tourism to advance community livelihoods in Musina Municipality, Limpopo, South Africa, encapsulate the raison d'être of this study: to analyze the extent to which sustainable tourism holds the key to advancing rural standards of living in the case of Musina Municipality, Limpopo, South Africa.

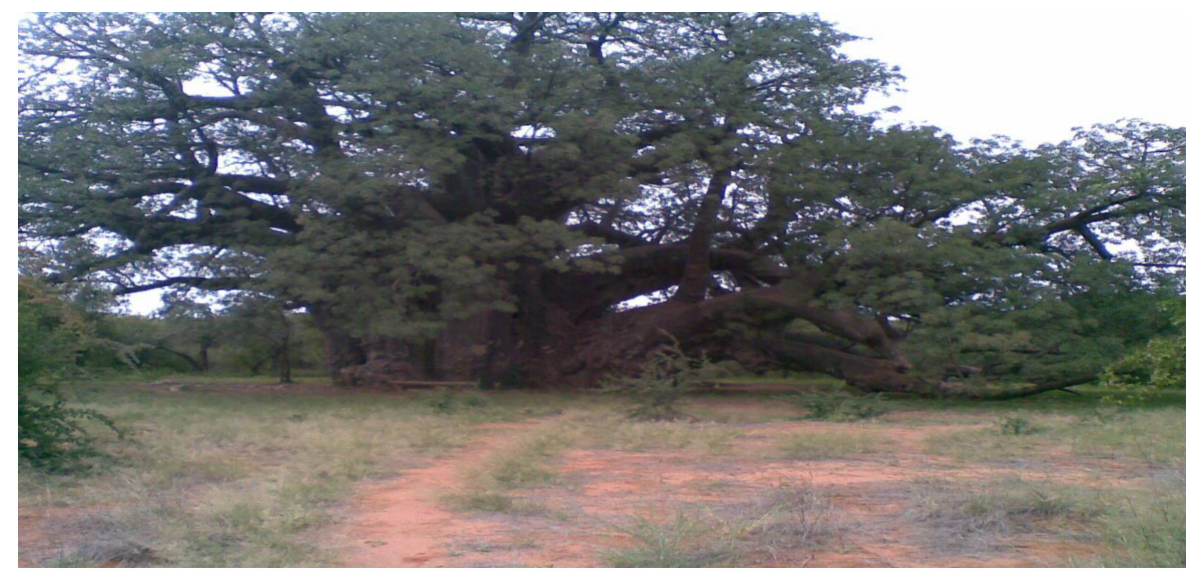

Source(s): Author, 2019



Source(s): Author, 2019
Mechanism to

\section{buoy community livelihoods}

Plate 1.

The big tree within the big tree nature reserve
Plate 2.

Infrastructural building within

Nwanedi Nature Reserve and Resort 

JBSED
1,1

\subsection{Prospects for sustainable tourism and community-based natural resource management (CBNRM) activities}

Community-based natural resource management (CBNRM) involves local people uniting to protect their land, water, animals and plants so that they can use these natural resources to improve their lives and the lives of their children and grandchildren. It revolves around the supposition that peoples whose habitats are endowed with a natural resource, from which they derive livelihood, evince a greater interest in sustainable land use than any government or external organization. The CBNRM empowers every active member of the community to play a significant role in enhancing the status of their lives on multiple dimensions economic, cultural and even spiritual. As a management system in symbiosis with nature, CBNRM embeds economics with natural resources preservation to engender long-lasting profit to the community. Successful CBNRM can yield a host of positive outcomes including but not limited to: access to resources, improvements in farming and food supply, creation of jobs, growth in SMEs, improved opportunities for education and training, development of community institutions, improvement in health and in life span, preservation of cultural heritage (DEAT, 2003; Ramaano, 2019). In addition, bioprospecting [3] can be integrated into CBNRM in serving sustainability, community development and sustainable tourism (Ramaano, 2019, 2021).

\section{Literature review}

Only a few studies are extant that explore the potential of sustainable tourism as a mechanism to buoy rural standards of living in South Africa. Opposing local economic empowerment solely on the basis of land reform, Govender van Wyk (2007) compared and endorsed various community-based tourism impacts on the livelihoods of local denizens in the Namaqualand Northern Cape. In turn, Acha Anyi (2014) investigated the actual impact on, and potential capacity to enhance, standards of living from sustainable tourism on Soshanguve communities. Snyman (2017) is adamant that ecotourism got implemented as a latent resolution for local development and biodiversity preservation in emerging countries. Dieke (2001) appraised the ecotourism potentials for both Kenya and South Africa. He views them as the most high-profiled address target within the sector. Eshun (2014) employed a mixed-method technique to examine the impacts of ecotourism based on a study of Kakum National Park and Boabeng-Fiema Monkey Sanctuary in Ghana. The study found that ecotourism is a fundamental vehicle for biodiversity protection in Ghana; however, its substantial contribution to livelihoods development remains insufficiently realized.

Concerning Okavango Delta in Botswana, Mbaiwa (2015) reflects on the milestone of years of ecotourism activities. He is resolute that its nature has been that of a two-way fold of success and failure associated with various factors such as lack of managerial and marketing skills. Goodwin (2008) observes a need to improve partnerships in ecotourism entities and local communities to facilitate substantial benefits. Ryan (2001) estimated the "unspoiled" nature of the marginalized South Pacific regions as a potential ecotourist benefit for the locals.

\section{Study area and methods}

\subsection{Location and characteristics}

Situated in the distant north-eastern part of the Limpopo Province, conterminous to Zimbabwe in the North and Mozambique on the East side next to the Kruger National Park, Musina Municipality forms part of the Vhembe District Municipality [4] (see Figure 1).

Generally, the Musina Municipality has an abundance of community-based natural resources potential judged by its natural biodiversity [5]. Various land uses - such as 


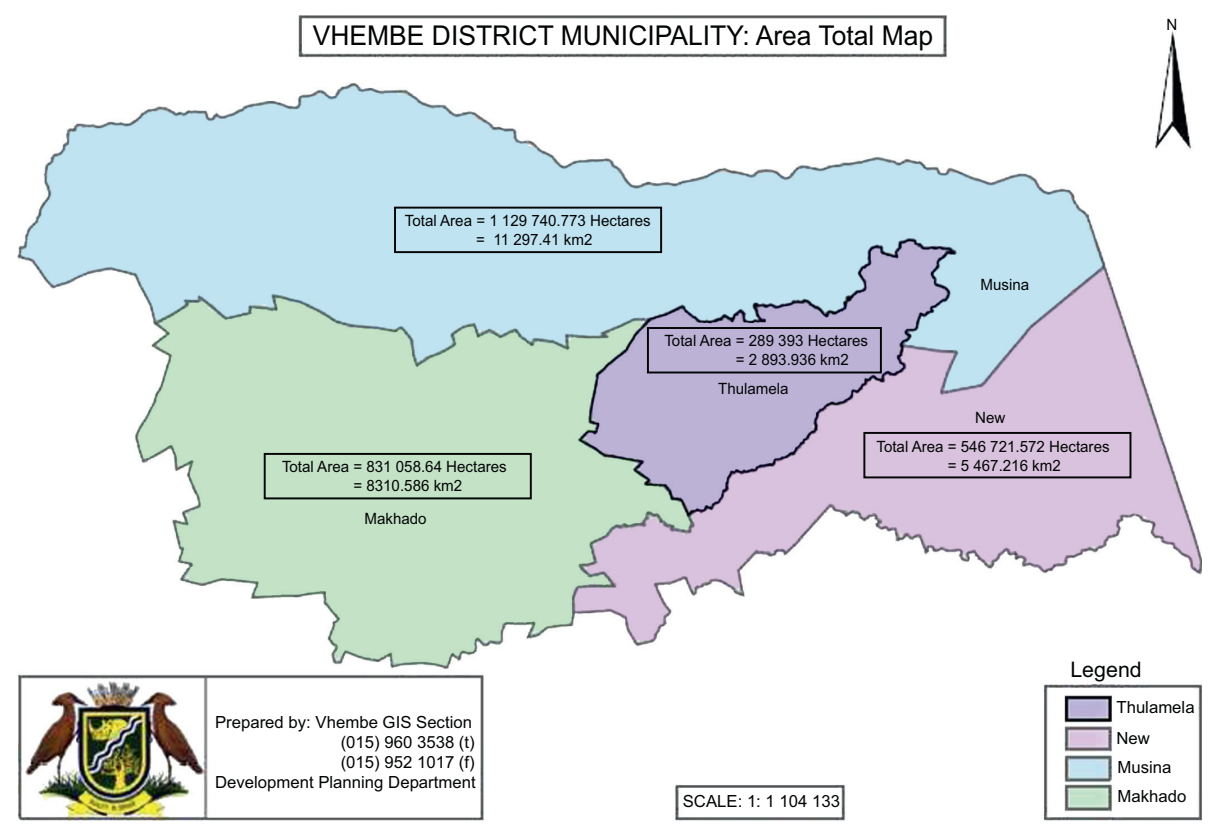

Mechanism to buoy community livelihoods

Source(s): Musina municipality, 2019

Figure 1. Location of the study

agriculture, game farming, hunting, mining, forestry and tourism - abound. Wilderness is plentiful sustained by annual rainfall of approximately $500 \mathrm{~mm}$ per annum (Poto and Mashela, 2008). Plate 3 shows the Tourism Information Center in Musina town, while Plate 4 presents Tshipise Forever Resort just outside Musina town (see Plate 2).

\subsection{Data and methods}

The methods utilized in this study intended to evaluate the prospects of using the tourism industry to advance community livelihoods in Musina Municipality, Limpopo, South Africa, based on intelligence garnered from local sources. The study employed a mixed-methods (quantitative/qualitative design) in which, apart from presentation of descriptive statistics, ANOVA is conducted. Primary data was drawn from purposive sampling [6] through questionnaires as the input for the qualitative analysis - with focus groups and interviews [7] serving as the primary basis for supplemental analysis using qualitative approach to such primary data. In that vein, primary data was extended to include field observation. Finally, some secondary data was gleaned from documentary sources. In the process, ethical research standards were observed and required permissions obtained.

3.2.1 Sample size calculation and rationale of the study. The sample size got calculated using Taro Yamane's formula (Yamane, 1973). $n=N /\left(1+N e^{2}\right)$, where $n$ is the sample size, $N$ is the population size and $e$ is the precision level. The presented study area includes Folovhodwe, Gumela, Tshipise and Zwigodini villages in Musina Municipality and has a population of 4,947. With a precision level set at $5 \%(e=0.05)$, the sample size of the study area was fixed at 370 . The degree of impoverishment and proximity of the villages to the protected areas influenced the choice of the study area. Ultimately, these four villages were orderly and purposefully selected. Folovhodwe, Gumela, Tshipise and Zwigodini are coterminous to various tourism 


\section{JBSED 1,1}

\section{2}

\section{Plate 3.}

Main infrastructure of the Musina Municipality tourism info

\section{Plate 4.}

Accommodation facility in Tshipise forever resort outside Musina town

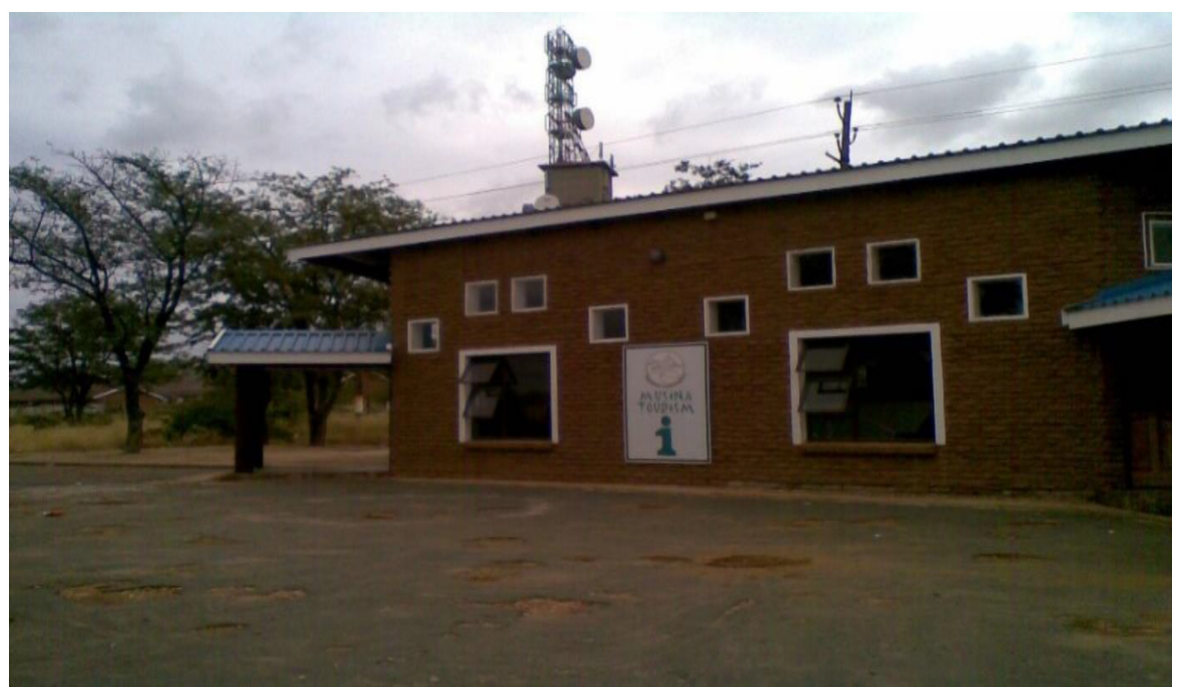

Source(s): Author, 2019

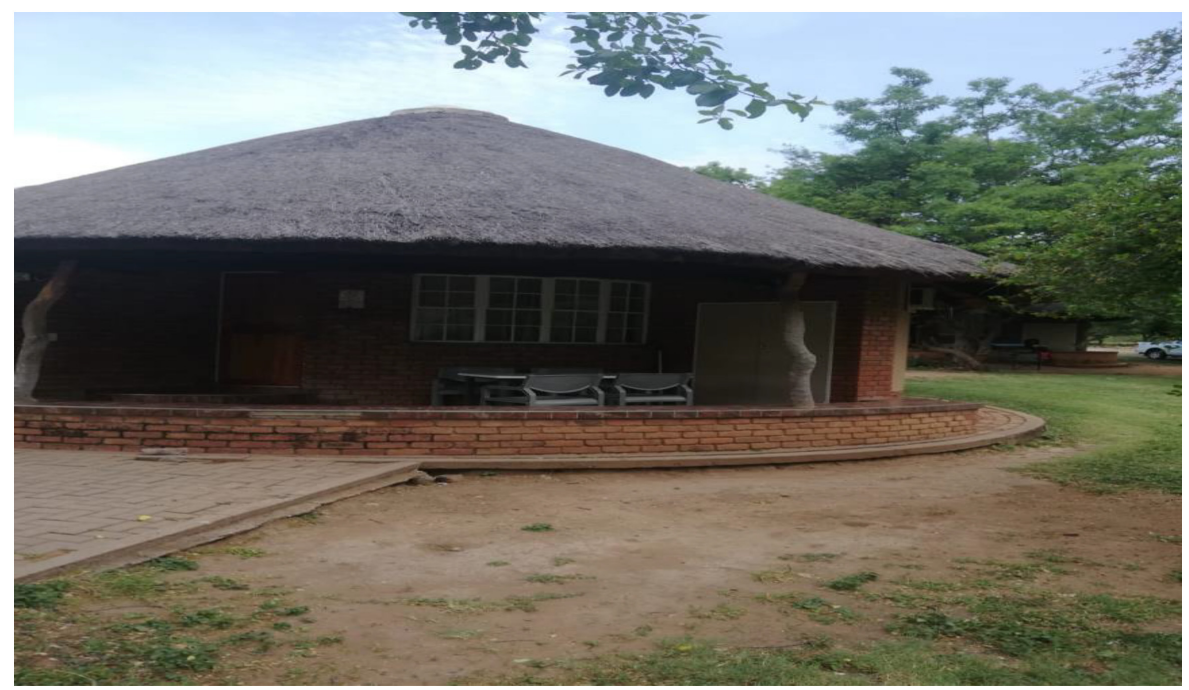

Source(s): Author, 2019

entities such as the Nwanedi Nature Reserve, Sagole Spa (Hot Spring) and the "Big Tree Nature Reserve," among the rest (Table 1). Table 1 displays the distribution of questionnaires within the sampled villages in the Musina municipal area. Table 2 presents the interviews undertaken with personnel affiliated with adjacent touristic entities in the study area.

To supplement data acquired through questionnaire surveys $(n=370)$, interviews $(n=30)$ and focus group discussions $(n=20)$ provided additional input. Field surveys served as a modality to cross-check data from other sources. For this study, the Musina previous Integrated 
Development Plan (IDP) and Local Economic Development (LED) strategies, in conjunction with a general review of the literature, served as lodestones for the acquisition of secondary data.

3.2.2 Analytical methods. Questionnaire survey is used to elicit responses from respondents whose demographic profile is evaluated using ANOVA to determine whether any key demographic (village habitation/household size/sex/education level) significantly impacts perceptions with respect to ecotourism potential (in terms of proximity and empowerment), actual livelihood benefit from ecotourism, actual ecotourism development activity levels and effectiveness of strategic economic turnaround plans. Accordingly, the following null hypotheses (NHs) are posited:

NH11. Village habitation has no effect on ecotourism potential in term of proximity.

NH12. Village habitation has no effect on ecotourism potential in terms of empowerment.

NH13. Village habitation has no effect on ecotourism potential in terms of actual ecotourism development activity levels.

NH14. Village habitation has no effect on ecotourism potential in terms of effectiveness of strategic economic turnaround plans.

NH21. Household size has no effect on ecotourism potential in term of proximity.

NH22. Household size has no effect on ecotourism potential in terms of empowerment.

NH23. Household size has no effect on ecotourism potential in terms of actual ecotourism development activity levels.

NH24. Household size has no effect on ecotourism potential in terms of effectiveness of strategic economic turnaround plans.

\begin{tabular}{lcc}
\hline Villages & Population & Questionnaires numbers per villages \\
\hline Folovhodwe & 2,806 & 211 \\
Gumela & 383 & 29 \\
Tshipise & 1,052 & 78 \\
Zwigodini & 706 & 52 \\
Total & 4,947 & 370
\end{tabular}

Source(s): Musina Municipality (2019)

Table 1.

Villages population and allocation of questionnaires

\begin{tabular}{|c|c|c|c|}
\hline Name of tourism ventures and their activities & $\begin{array}{l}\text { Location of the tourism venture } \\
\text { (villages) }\end{array}$ & $\begin{array}{c}\text { Interviewees per venture/ } \\
\text { entity }\end{array}$ & \multirow{9}{*}{$\begin{array}{r}\text { Table 2. } \\
\text { Tourism ventures and } \\
\text { allocations of } \\
\text { interviews from } \\
\text { designated } \\
\text { questionnaires on } \\
\text { tourism ventures } \\
\text { personnel }\end{array}$} \\
\hline $\begin{array}{l}\text { Nwanedi nature reserve and resort, } \\
\text { (Luphephe dam) }\end{array}$ & Gumela (/Folovhodwe) villages & 5 & \\
\hline The big tree holiday accommodation & Zwigodini (Madifha) village & 5 & \\
\hline $\begin{array}{l}\text { Manalani lodge; (Sagole spa geothermal } \\
\text { spring) }\end{array}$ & Tshipise village & 5 & \\
\hline $\begin{array}{l}\text { The Big tree nature reserve (big baobab and } \\
\text { mopani trees) }\end{array}$ & Zwigodini (Madifha) village & 5 & \\
\hline Beria Madzonga resort & Zwigodini village & 5 & \\
\hline Musina LED and Tourism info & $\begin{array}{l}\text { Musina municipality (Musina } \\
\text { town) }\end{array}$ & 5 & \\
\hline Total & 6 & 30 & \\
\hline Source(s): Musina Municipality (2019) & & & \\
\hline
\end{tabular}


JBSED

1,1

\section{4}

NH31. Sex distribution has no effect on ecotourism potential in term of proximity.

NH32. Sex distribution has no effect on ecotourism potential in terms of empowerment.

NH33. Sex distribution has no effect on ecotourism potential in terms of actual ecotourism development activity levels.

NH34. Sex distribution has no effect on ecotourism potential in terms of effectiveness of strategic economic turnaround plans.

NH41. Education level has no effect on ecotourism potential in term of proximity.

NH42. Education level has no effect on ecotourism potential in terms of empowerment.

NH43. Education level has no effect on ecotourism potential in terms of actual ecotourism development activity levels.

NH44. Education level has no effect on ecotourism potential in terms of effectiveness of strategic economic turnaround plans.

NH51. Economic privation perception has no effect on ecotourism potential in term of proximity.

NH52. Economic privation perception has no effect on ecotourism potential in terms of empowerment.

NH53. Economic privation perception has no effect on ecotourism potential in terms of actual ecotourism development activity levels.

NH54. Economic privation perception has no effect on ecotourism potential in terms of effectiveness of strategic economic turnaround plans.

Qualitative analysis is used to corroborate results from the hypotheses testing and to provide additional insights into the results obtained.

\section{Results and discussions}

\subsection{Descriptive statistics}

This results section presents information on the geographical, household size, sex and education profiles of respondents in the study area.

4.1.1 Distribution by geography (village) of the respondents. This section presents the sample and population size of each of the four villages: Folovhodwe $(2,806)$, Gumela (383), Tshipise $(1,052)$ and Zwigodini (706) (Table 3). The official unemployment rate of the population is $48.8 \%$. The youth unemployment rate (15-34 age group) is $62.2 \%$. Femaleheaded households shifted from $44.6 \%$ in 2011 to $43.4 \%$ in 2016 . Hence, the $15-64$ age group comprises $67.1 \%$ of the population. $30.5 \%$ are under 15 years old of age. Class distribution stands at $94 \%$ blacks and 5\% whites within the Municipality. The Vha-Venda tribe is the dominant ethnic group. Agriculture manifests private, land commercial horticultural and livestock farming and small-scale crop farming as primary economic activities (Musina Municipality, 2007, 2017, and 2019).

4.1.2 Distribution by household size of the respondents. Driving basic community needs, household size evinces "a strong negative correlation with consumption (or income) per capita in developing countries" Lanjouw and Ravallion (1995) that ecotourism strategy needs to account for at the community level for achieving sustainable development as a motor for rural employment. Among total respondents in the survey, the household size ranged from 1 to 2 to $7+$ members; however, the bulk of the household size (37.2\%) comprises 3-4 and 5-6 members apiece as depicted in Table 4. (See graphical depiction in Figure 2). In contrast, $13.4 \%$ of respondents have $7+$ members and, in the smallest segment, only $11.6 \%$ of the 
respondents have 1-2 members. Household size provides insights into the sources and consequences of impoverishment and for the demand of basic needs such as energy, food security, education, health and sanitation. Food security entails the stability of supplies, food availability and accessibility to the household members (Maxwell, 2001). Obtaining data on the household sizes sheds light on socioeconomic status and impoverishment within communities.

Mechanism to buoy community livelihoods

\begin{tabular}{|c|c|c|c|c|}
\hline Villages & Population & $\begin{array}{l}\text { Calculation formula and } \\
\text { percentages }\end{array}$ & $\begin{array}{l}\text { Sample } \\
\text { size }\end{array}$ & \\
\hline $\begin{array}{l}\text { Folovhodwe[Next to Nwanedi nature reserve, } \\
\text { Tshipise forever resort and Tanda village] }\end{array}$ & 2,806 & $\begin{array}{l}57 \% \times 370=210.9 \text { (Rounded } \\
\text { to } 211)=211\end{array}$ & 211 & \\
\hline Gumela[Next to Nwanedi resort, Luphephe dam] & 383 & $8 \% \times 370=29$ & 29 & \\
\hline $\begin{array}{l}\text { Tshipise[Next to Sagole spa, Dambale bushmen } \\
\text { rock paintings and Domboni village and caves] }\end{array}$ & 1,052 & $\begin{array}{l}21 \% \times 370=77.7 \text { (Rounded } \\
\text { to } 78)=78\end{array}$ & 78 & \\
\hline $\begin{array}{l}\text { Zwigodini[Next to the Big tree nature reserve, Big } \\
\text { tree accommodation lodge and Madifha village] }\end{array}$ & 706 & $\begin{array}{l}14 \% \times 370=51.8(\text { Rounded } \\
\text { to } 52)=52\end{array}$ & 52 & $\begin{array}{r}\text { Table } 3 . \\
\text { Distribution bv }\end{array}$ \\
\hline Total & 4,947 & $100 \%$ & 370 & geography [Villages \\
\hline Source(s): Musina Municipality (2019) & & & & and sample size] \\
\hline
\end{tabular}

\begin{tabular}{|c|c|c|c|c|c|c|}
\hline & & $\begin{array}{l}\text { ld size profile } \\
1-2\end{array}$ & $3-4$ & $5-6$ & $7+$ & Total \\
\hline \multirow{2}{*}{ Gumela } & Count & 1 & 12 & 11 & 5 & 29 \\
\hline & $\%$ & 3.4 & 41.3 & 37.9 & 17.2 & 100.0 \\
\hline \multirow[t]{2}{*}{ Folovhodwe } & Count & 25 & 77 & 76 & 33 & 211 \\
\hline & $\%$ & 11.8 & 36.4 & 36.0 & 15.6 & 100.0 \\
\hline \multirow[t]{2}{*}{ Tshipise } & Count & 12 & 29 & 31 & 6 & 78 \\
\hline & $\%$ & 15.3 & 37.1 & 39.7 & 7.6 & 100.0 \\
\hline \multirow[t]{2}{*}{ Zwigodini } & Count & 5 & 20 & 20 & 7 & 52 \\
\hline & $\%$ & 9.6 & 38.4 & 38.4 & 13.4 & 100.0 \\
\hline \multirow[t]{2}{*}{ Total } & Count & 43 & 138 & 138 & 51 & 370 \\
\hline & $\%$ & 11.6 & 37.2 & 37.2 & 13.7 & 100.0 \\
\hline
\end{tabular}

Source(s): Survey by the Author, 2019

Table 4.

Distribution by household size of the respondents

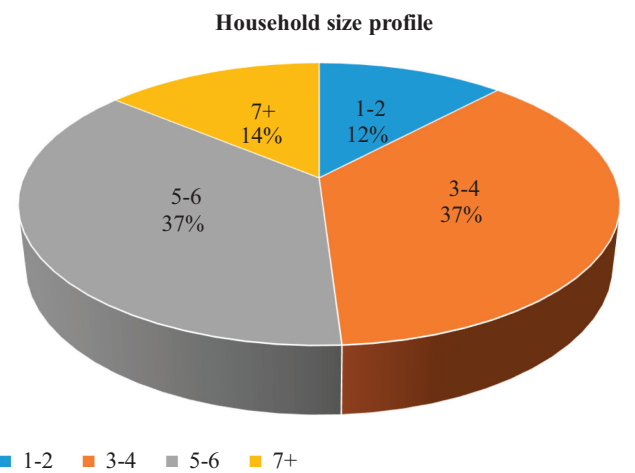

Source(s): Author's field data, 2019

Figure 2. Household size profile 

JBSED
1,1

56

4.1.3 Distribution by sex of the respondents. Of the sample size of 370, 205 are men and 165 are women. In terms of demographics, Ramaano (2021) determined that the population of the study area consists of $55 \%$ men and $45 \%$ women. The sample size [men $(55.4 \%)$ /women $(44.5 \%)$ ] (Table 5) roughly comports with that above-cited distribution of population identified by Ramaano.

4.1.4 Distribution by educational level of the respondents. Perceptions with respect to ecotourism and environmental activities may reflect differences in educational levels attained by segments of the sampled population. Table 6 [8] depicts the educational status of the respondents in the Musina municipal area. (See graphical depiction in Figure 3). Among total surveyed respondents, the same number have obtained secondary level as have obtained only elementary level of education - that is $33.7 \%$. However, $21.8 \%$ have undergone some education at the tertiary level with only $11.6 \%$ lacking any formal education. Presumably, the higher the level of educational attainment, the greater the capacity of any member of the community to contribute productively to (in addition to comprehend better the role of) regionally- and locally ordained policy and strategies designed to promote ecotourism, community development and environmental management. In addition, well-funded sustainable ecotourism can finance the educational achievements of the community through tertiary education sponsorships.

4.1.5 Distribution in perception of economic privation of the respondents. Data in Table 7 [9] indicate that a total of 138 respondents $(37.2 \%)$ identified "inadequate biodiversity maintenance" as the centerpiece of their day-to-day challenges. However, 108 respondents

\begin{tabular}{llccc}
\hline & & Gender profile & & Male \\
Female & Total \\
\hline Gumela & Count & 12 & 17 & 29 \\
& $\%$ & 41.3 & 58.6 & 100.0 \\
Folovhodwe & Count & 102 & 109 & 211 \\
& $\%$ & 48.3 & 51.6 & 100.0 \\
Tshipise & Count & 29 & 49 & 78 \\
& $\%$ & 37.1 & 62.8 & 100.0 \\
Zwigodini & Count & 22 & 30 & 52 \\
& $\%$ & 42.3 & 57.6 & 100.0 \\
Total & Count & 165 & 205 & 370 \\
& $\%$ & 44.5 & 55.4 & 100.0
\end{tabular}

Table 5 . the respondents

Source(s): Survey by the Author, 2019

\begin{tabular}{llccccc}
\hline & & $\begin{array}{c}\text { Education profile } \\
\text { No formal }\end{array}$ & Primary & Secondary & Tertiary & Total \\
\hline Gumela & Count & 1 & 6 & 20 & 2 & 29 \\
& $\%$ & 3.4 & 20.6 & 68.9 & 6.8 & 100.0 \\
Folovhodwe & Count & 27 & 70 & 69 & 45 & 211 \\
& $\%$ & 12.7 & 33.1 & 32.7 & 21.3 & 100.0 \\
Tshipise & Count & 9 & 25 & 20 & 24 & 78 \\
& $\%$ & 11.5 & 32.0 & 25.6 & 30.7 & 100.0 \\
Zwigodini & Count & 6 & 20 & 16 & 10 & 52 \\
& $\%$ & 11.5 & 38.4 & 30.7 & 19.2 & 100.0 \\
Total & Count & 43 & 121 & 125 & 81 & 370 \\
& $\%$ & 11.6 & 32.7 & 33.7 & 21.8 & 100.0
\end{tabular}

Source(s): Survey by the Author, 2019

Table 6.

Distribution by education level of the respondents 


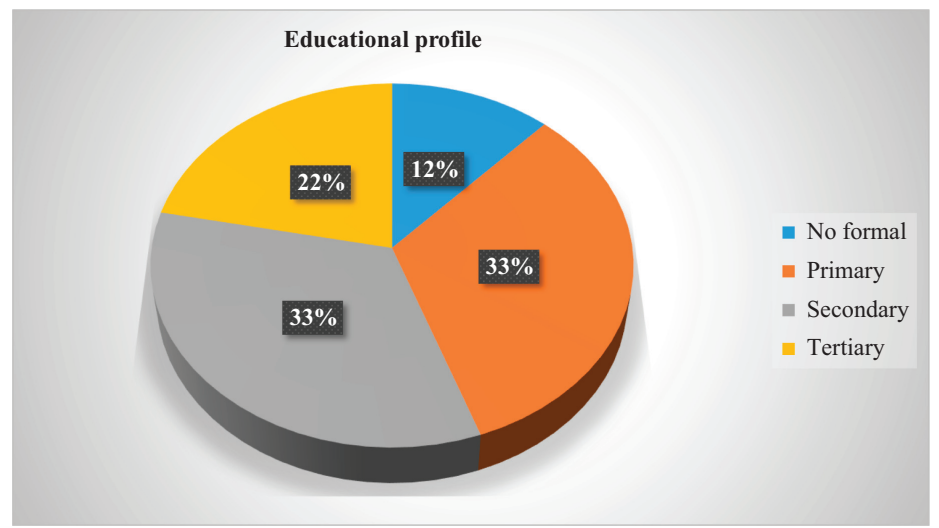

Mechanism to

buoy
community
livelihoods

Source(s): Author's field data, 2019

Figure 3. Educational profile

$(29.1 \%)$ chose "inefficient water services" and 57 respondents $(15.4 \%)$ selected "shortage of adequate health facilities," whereas 35 respondents chose "lack of electricity supply." On the other hand, an overall total of just 17 respondents selected "food insecurity." No respondents checked "poor education" or "others" challenges. Information obtained through focus groups corroborated these findings ordering gaps in service priorities in descending order [10]. Data delimiting precedence of service delivery deficiencies for most villages in rural areas - namely inefficient water services, inadequate health services and, in particular, inadequate biodiversity management - comport with the findings of Ramaano (2019) in many rural areas in Limpopo. Thus, in this study, the prospect of using the tourism industry to advance community livelihoods should rest on devising a holistic and comprehensive strategy that capitalizes on the synergies among all valuable resources and biodiversity in the study area. Therefore tourism is an incentive, trendsetter and motivating aspect for comprehensive development. Hence, the latter will curb the debilitating challenges such as inefficient water services, inadequate health services and biodiversity management in the study area.

\subsection{Tourism potential within the study area}

4.2.1 Responses from the community with respect to tourism venture proximity. Data in (Table 8) [11] indicate that a majority total of 240 respondents $(64.8 \%)$ identified the Nwanedi Nature Reserve and Resort as the most proximate venture or activity in relation to their domicile that they are aware of in their local area. In contrast, a moderate number of 78 respondents likewise identified Tshipise Sagole spa, whereas only 52 respondents $(14.0 \%)$ so identified The Big Tree Nature Reserve. Nwanedi nature reserve and resort is dominant in the environs of Gumela and Folovhodwe villages. In actuality, all the ventures are the major ones within their respective villages. In the same vein, $100 \%$ of respondents from discussion held with focus groups $(n=20)$ shared the same impressions with respect to proximity. [12] Photographic evidence corroborates the accuracy of these observations. (See also Plates 1 and 3). Representatives from six adjacent tourism ventures and entities from the Nwanedi Nature Reserve, the Big Tree Nature Reserve, the Big Tree Holiday Accommodation, Beria Madzonga Resort, Manalani Lodge and Musina LED and Tourism Info Entity confirm that there is ecotourism potential within their areas [13].

4.2.2 Impacts of tourism activities on the livelihoods of local communities in the study area. 4.2.2.1 Responses on any empowerment or benefits from the adjacent tourism venture. Data in (Table 9) indicate that 346 respondents responded negatively, thus, if any welfare, from the tourism enterprises. The other 24 respondents replied positively to receiving something from 
JBSED

1,1

58

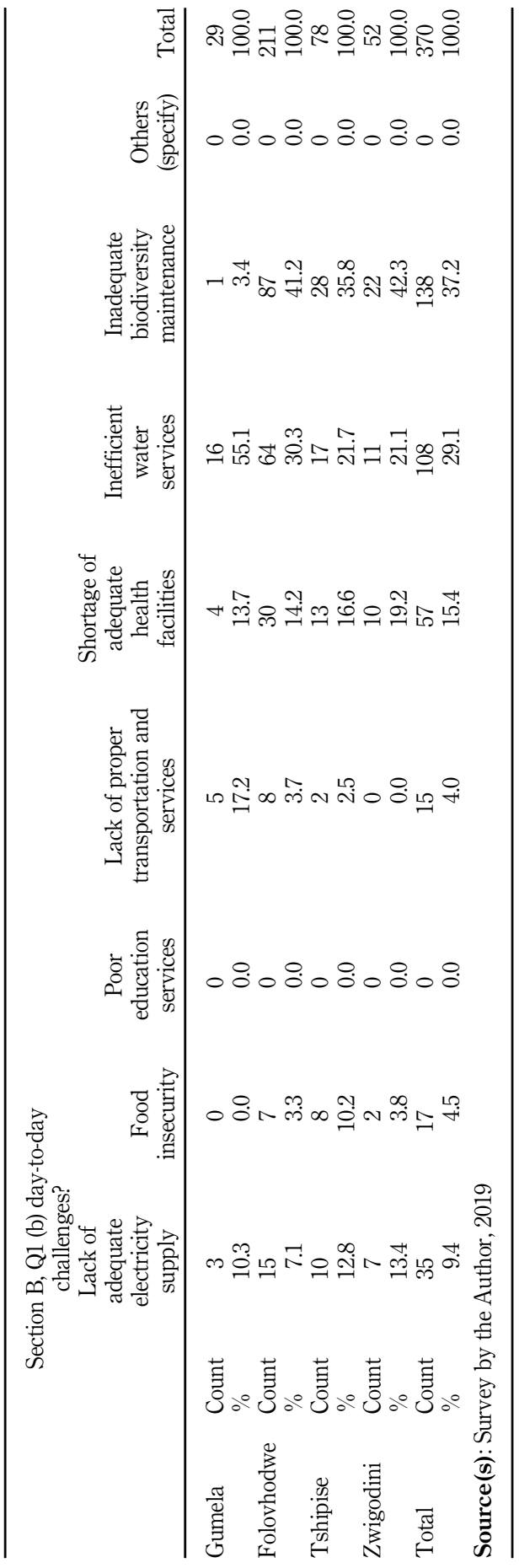

Table 7.

Distribution in

perception of economic privation of the respondents 
Table 8. Responses from the community with respect to tourism venture proximity 


\begin{tabular}{|c|c|c|c|c|c|}
\hline \multirow[t]{2}{*}{$\begin{array}{l}\text { JBSED } \\
1,1\end{array}$} & \multicolumn{5}{|c|}{$\begin{array}{l}\text { Section B, Q2 (b) do you receive any empowerment or } \\
\text { benefits from the adjacent tourism venture? }\end{array}$} \\
\hline & & & No & Yes & Total \\
\hline \multirow{3}{*}{60} & Gumela & $\begin{array}{l}\text { Count } \\
\%\end{array}$ & $\begin{array}{l}22 \\
75.8\end{array}$ & $\begin{array}{c}7 \\
24.1\end{array}$ & $\begin{array}{c}29 \\
100.0\end{array}$ \\
\hline & Folovhodwe & $\begin{array}{l}\text { Count } \\
\%\end{array}$ & $\begin{array}{c}201 \\
952\end{array}$ & $\begin{array}{c}10 \\
47\end{array}$ & 211 \\
\hline & Tshipise & Count & 76 & 2 & 78 \\
\hline \multirow{4}{*}{$\begin{array}{l}\text { Table } 9 \text {. } \\
\text { Responses on any } \\
\text { empowerment or } \\
\text { benefits from the } \\
\text { adjacent tourism } \\
\text { venture }\end{array}$} & Zwigodini & $\begin{array}{l}\% \\
\text { Count }\end{array}$ & $\begin{array}{l}97.4 \\
47\end{array}$ & $\begin{array}{l}2.5 \\
5\end{array}$ & $\begin{array}{c}100.0 \\
52\end{array}$ \\
\hline & & $\%$ & 90.3 & 9.6 & 100.0 \\
\hline & Total & $\begin{array}{l}\text { Count } \\
\%\end{array}$ & $\begin{array}{c}346 \\
93.5\end{array}$ & $\begin{array}{c}24 \\
6.4\end{array}$ & $\begin{array}{l}370 \\
100.0\end{array}$ \\
\hline & Source(s): & thor, 20 & & & \\
\hline
\end{tabular}

such enterprises. Consequently, a majority of (93.5\%) respondents responded [No] opposed by only $(6.4 \%)$ who indicated [Yes] to receiving any empowerment from such ventures and entities $(n=370)$. [Questionnaire survey within the four sampled villages distributed between the morning of March 1 and afternoon April 30 and collected between the morning of May 15 and afternoon June 15,2019]. It shows that tourism issues are not run proficiently within the study area. Thus, current tourism developments seem to do less to capacitate the economy and livelihoods of the communities. Therefore, there is an urgent obligation to improve tourism endeavors, thus, underpinned by a robust master plan and tourism strategy. There exist possibilities to advance the communities in the study area. On the same note, the study revealed that $76.6 \%$ of the interviewed respondents within tourism ventures and entities conveyed that they do not know about other tourism ventures and entities empowering the adjacent local communities around them. The $23.3 \%$ indicated to have some knowledge about such empowerment on locals $(n=30)$ (Key informant interviews within the six sampled tourism ventures and entities April 8/9/10, 2019, during the mornings and afternoons). Likewise, $95 \%$ of respondents from focus group discussions expressed the same on not getting enough benefits from tourism welfare $(n=20)$ (Focus group discussions within all the sampled villages [mornings and afternoons] March 17/18/19/20, 2019). Hence, both document review and physical observation assisted in such data through literature reviews and pictures of some neglected tourism activities.

4.2.2.2 Responses on how tourism benefits affect their livelihoods and daily basis. Data in Table 10 [14] indicate that a majority total of 337 respondents $(91.0 \%)$ replied "none" to socioeconomic benefits from the use of main or any tourism enterprise within or nearby their area. Another 33 respondents $(8.9 \%)$ responded to be "insignificant" with respect to receiving socioeconomic benefits from the aforementioned ventures and entities. Not a single respondent indicated either a "significant" or "very significant" benefit. These reported perceptions indicate that extant ecotouristic activities are not contribution to amelioration of the economic livelihoods of the indigenous proximate populations. Of the interviewed respondents within tourism ventures and entities conveyed, considered collectively, only seven respondents $(23.3 \%)$ responded affirmatively to awareness of tourism ventures and entities having a significant positive impact on proximate local communities. However, the majority of such respondents accorded some positive aspect of only the form of a "trickledown" effect. [About $90 \%$ of respondents from focus groups shared the same sentiments on this instance $(n=20)$ [15]]. From the Big Tree Nature Reserve (Zwigodini Madifha), however, all respondents maintained that local people enjoy employment opportunities from the extant ecotourism enterprises in their local area of habitation. In a similar vein, many respondents 


\begin{tabular}{|c|c|c|c|c|c|c|c|}
\hline & $\begin{array}{r}\text { Sectior } \\
\text { aff } \\
\text { liveliho }\end{array}$ & $\begin{array}{l}\text { B, Q2 (b) (ii) } \\
\text { ct your socioe } \\
\text { ds and daily } \\
\text { the table } \\
\text { None } \\
\text { (nothing at } \\
\text { all) }\end{array}$ & $\begin{array}{l}\text { W us how does it } \\
\text { nomic status, } \\
\text { basic needs from } \\
\text { low? } \\
\text { Insignificantly } \\
\text { (not enough) }\end{array}$ & $\begin{array}{l}\text { Significantly } \\
\text { (enough) }\end{array}$ & $\begin{array}{l}\text { Very significantly } \\
\text { (more than enough) }\end{array}$ & Total & $\begin{array}{r}\text { lechanism to } \\
\text { buoy } \\
\text { community } \\
\text { livelihoods }\end{array}$ \\
\hline \multirow[t]{2}{*}{ Gumela } & \multirow{2}{*}{$\begin{array}{l}\text { Count } \\
\%\end{array}$} & \multirow{2}{*}{$\begin{array}{l}16 \\
55.1\end{array}$} & \multirow{2}{*}{$\begin{array}{l}13 \\
44.8\end{array}$} & \multirow{2}{*}{$\begin{array}{l}0 \\
0.0\end{array}$} & \multirow{2}{*}{$\begin{array}{l}0 \\
0.0\end{array}$} & \multirow{2}{*}{$\begin{array}{c}29 \\
100.0\end{array}$} & \multirow{10}{*}{$\begin{array}{r}\text { Table 10. } \\
\text { Responses on how } \\
\text { tourism benefits affect } \\
\text { their livelihoods and } \\
\text { daily basic needs }\end{array}$} \\
\hline & & & & & & & \\
\hline \multirow[t]{2}{*}{ Folovhodwe } & Count & 198 & 13 & 0 & 0 & 211 & \\
\hline & $\%$ & 93.8 & 6.1 & 0.0 & 0.0 & 100.0 & \\
\hline \multirow[t]{2}{*}{ Tshipise } & Count & 75 & 2 & 0 & 0 & 78 & \\
\hline & $\%$ & 96.1 & 3.8 & 0.0 & 0.0 & 100.0 & \\
\hline \multirow[t]{2}{*}{ Zwigodini } & Count & 47 & 5 & 0 & 0 & 52 & \\
\hline & $\%$ & 90.3 & 9.6 & 0.0 & 0.0 & 100.0 & \\
\hline \multirow[t]{2}{*}{ Total } & Count & 337 & 33 & 0 & 0 & 370 & \\
\hline & \multicolumn{4}{|c|}{ Source(s): Survey by the Author, 2019} & & 100.0 & \\
\hline
\end{tabular}

from the LED and Tourism info Center (Musina municipal offices) shared the impression that local inhabitants benefit from the tourism ventures around them through the belief that these denizens benefit by selling off their local produce and artifacts to tourists who visit the environs. To a lesser extent, these informants report that some of the locals secure employment within ventures and entities affiliated with ecotourism. Similar sentiments were noted from respondents from Nwanedi nature reserve and resort (Gumela and Folovhodwe villages gates) who likewise underscored, consonant with the responses gleaned from the LED and Tourism info Center (Musina municipal offices), that local inhabitants enjoy pecuniary advantages from opportunities afforded by local ecotourism.

4.2.3 Major potential tourism development attraction activities within the study area. 4.2.3.1 Responses on major potential tourism development attraction activities in their area. Data in Table 11 [16] show that a total of 182 respondents $(49.1 \%)$ indicated that various tree species [17] hold major potential as sources for the attraction of tourists to visit the local environs in which they reside. Other respondents indicated other major local potential tourism development attractions: 97 respondents (26.2\%) selected agricultural sites; 34 respondents $9.1 \%$, art crafts; 19 respondents, natural heritage; but only 8 respondents, ancient rock paintings. In contrast, 28 respondents $(7.5 \%)$ chose nil indicative of their conviction that there is no major potential source of ecotouristic attraction. Not a single respondent indicated any confidence that game reserves and accommodation lodges hold ecotouristic prospects. [About 95\% of respondents from focus group discussions [18] shared the similar impressions on the distribution of sources linked to ecotouristic potential.]

However, secondary (documentary) sources, while recognizing the potential of indigenous species and resources as a potential basis for generating income through ecotourism that can percolate throughout the community (Ramaano, 2019, 2021), stipulate some limitations to sustainability of ecotourism specifically derived from plant and tree species. Shackleton $\mathrm{et}$ al. (2007) showed that forests and savannas furnish have been harnessed with mixed success to buoy the prosperity of rural communities with the degree of success in generating sustainable livelihoods depending on the extent of the alignment of conservation with poverty alleviation plans and policies. Different ecosystems offer alternative bases of ecotourism with varied potential for sustainable economic activities. What may hold great potential in one region for instance, the Central Himalayas [19] - may hold much less potential in another. An exception, however, may be fuel wood [20]. 
JBSED

1,1

62

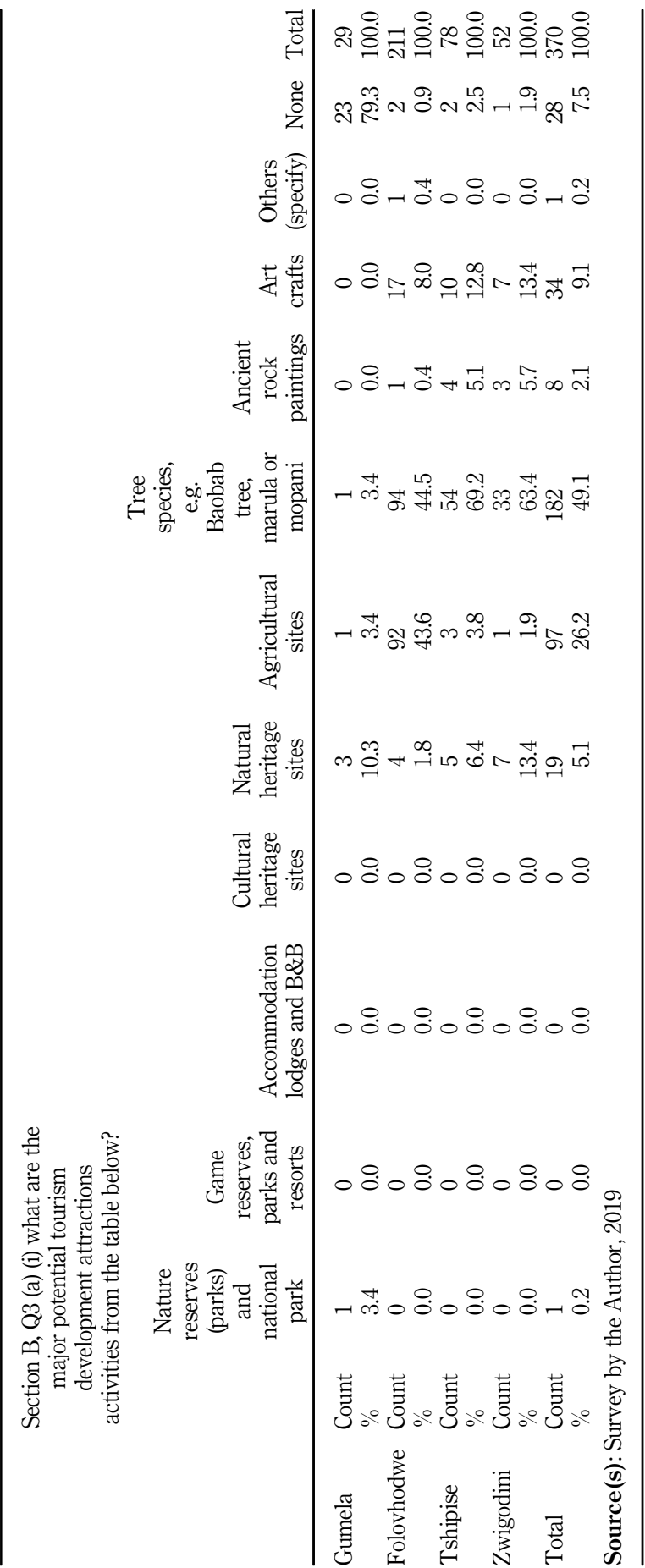

Table 11.

Responses on major potential tourism development attraction activities in their area

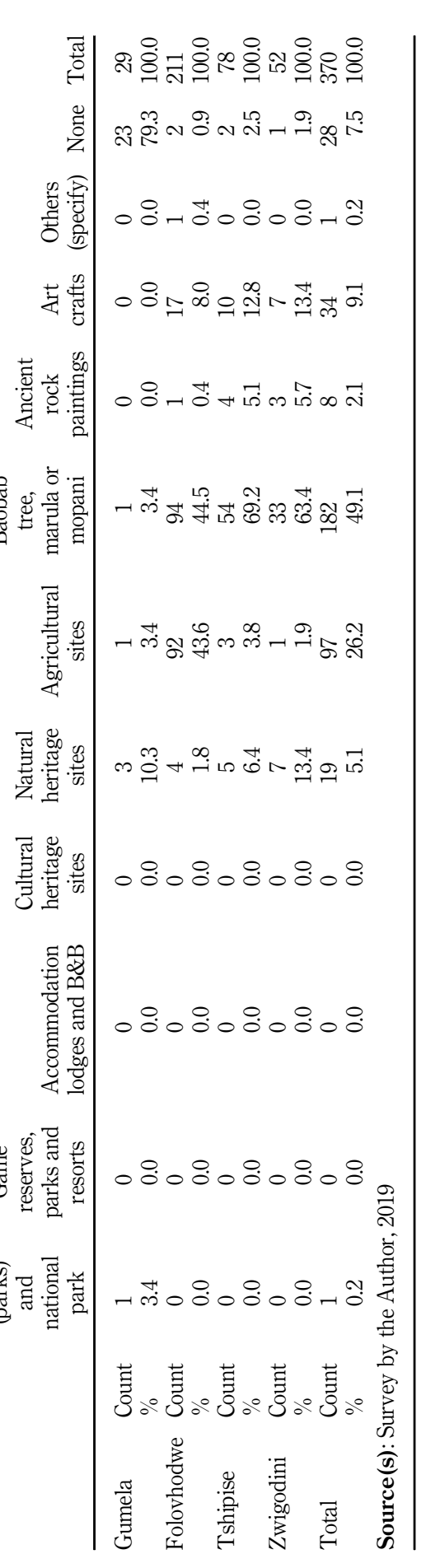


4.2.3.2 Broad view on the usages of significant plant and tree species for livelihoods in the study area. In Musina, potential sustainable usage of biomass for buoying community livelihoods abound (Ramaano, 2019). Cases in point, identified by Ramaano (2021), are plant species such as aloe vera, which can play a vital role within medical tourism fostering economic development on the community level. In addition, Marula trees [Sclerocarya birrea], harvested and processed for brewing marula beers, and, likewise, Baobabs [Adansonia digitata], cultivated not only for their fruits, but also for cosmetic oil extracted from their bark and seedlings. Ventures such as Nwanedi Nature Reserve and Tshipise Resort have accommodation chalets with access to marula beer taps. Local community-based initiatives involving inputs from Community Tourism (CT), bioprospecting of natural resources and CBNRM offer the greatest potential for sustainable ecotourism involving community entrepreneurship. Supplying ecotouristic enterprises with a sustainable harvest of fuel wood, from local community producers, could be a beneficial undertaking.

4.2.4 Turnaround strategy for communities and environmental sustainability of tourism. 4.2.4.1 Responses with respect to actual knowledge concerning village-level turnaround strategy. Data in Table 12 [21] indicate that, among 359 respondents (97.0\%), no knowledge prevails of any turnaround or improvement strategy undertaken by local communities for the betterment of environmentally sustainable tourism in their villages. Only 11 respondents $(2.9 \%)$ responded positively to having such knowledge. Likewise, $95 \%$ of respondents from focus group discussions [22] expressed no knowledge of turnaround strategy within their communities. Among the interviewed respondents within tourism ventures and entities, [23] $93.3 \%$ affirmed that there is no turnaround strategy planned concerning the betterment of the environmental sustainability of tourism and sustainability in the study area. Almost all of the remainder $(6.6 \%)$ conceded at most a modicum of development currently in incipient planning stages. Only two respondents [24] responded affirmatively about the existence of a turnaround strategy designed to serve as a fillip to buoy sustainable ecotourism. To that end, they mentioned the planned building of other tourism parks within villages of the Musina Municipality serving to curb possible detrimental effects of conventional tourism with a view to ultimately preserving the biodiversity.

\subsection{Hypotheses testing}

Null hypotheses $\sum_{X=1}^{5} \sum_{Y=1}^{5} \mathrm{NH}_{x y}$ are accepted. This means that neither village habitation, nor household size, nor sex distribution nor educational level nor perception of economic

\begin{tabular}{|c|c|c|c|c|c|}
\hline & $\begin{array}{r}\text { Section } \\
\text { your } 1 \\
\text { susta } \\
\end{array}$ & $\begin{array}{l}y \text { turna } \\
\text { the bet } \\
\text { nd ove } \\
\text { the loc } \\
\text { No }\end{array}$ & $\begin{array}{l}\text { nned by } \\
\text { mental } \\
\text { within } \\
\text { Yes }\end{array}$ & Total & \\
\hline Gumela & $\begin{array}{l}\text { Count } \\
\%\end{array}$ & $\begin{array}{l}25 \\
86.2\end{array}$ & $\begin{array}{c}4 \\
13.7\end{array}$ & $\begin{array}{c}29 \\
100.0\end{array}$ & \\
\hline Folovhodwe & $\begin{array}{l}\text { Count } \\
\%\end{array}$ & $\begin{array}{c}209 \\
99.0\end{array}$ & $\begin{array}{l}2 \\
0.9\end{array}$ & $\begin{array}{l}211 \\
100.0\end{array}$ & \\
\hline Tshipise & $\begin{array}{l}\text { Count } \\
\%\end{array}$ & $\begin{array}{l}75 \\
96.1\end{array}$ & $\begin{array}{l}3 \\
3.8\end{array}$ & $\begin{array}{c}78 \\
100.0\end{array}$ & \\
\hline Zwigodini & $\begin{array}{l}\text { Count } \\
\%\end{array}$ & $\begin{array}{l}50 \\
96.1\end{array}$ & $\begin{array}{l}2 \\
3.8\end{array}$ & $\begin{array}{c}52 \\
100.0\end{array}$ & $\begin{array}{r}\text { Table } 12 . \\
\text { Responses with respect } \\
\text { to actual knowledge }\end{array}$ \\
\hline Total & $\begin{array}{l}\text { Count } \\
\%\end{array}$ & $\begin{array}{c}359 \\
97.0\end{array}$ & $\begin{array}{c}11 \\
2.9\end{array}$ & $\begin{array}{l}370 \\
100.0\end{array}$ & $\begin{array}{r}\text { concerning village- } \\
\text { level turnaround }\end{array}$ \\
\hline \multicolumn{5}{|c|}{ Source(s): Survey by the Author, 2019} & strategy \\
\hline
\end{tabular}

Mechanism to

$$
\begin{array}{r}
\text { buoy } \\
\text { community } \\
\text { livelihoods }
\end{array}
$$

63 

$\underset{1,1}{\text { JBSED }}$

64

privation impacts perceptions of ecotourism potential (in terms of both proximity and empowerment), appraisal of actual ecotourism activities and effectiveness of strategic economic turnaround plans. Economic potential of ecotourism is assessed as very high. However, the level of actual ecotouristic activities undertaken in Musina Municipality vastly dwarfs this potential and remains largely unrealized. Ecotourism development activities are not sufficiently empowering local communities in the study area. While, locally, part of the economy, tourism is not, as practiced, a sustainable practice and deviates from ecotourism. Strategic economic turnaround plans for the local area are widely regarded as a failure. Coordination between local communities, Government and Nongovernmental Organisations dealing with ecotourism, together with local and external stakeholders, is not at a level sufficient to generate sustainable growth with a view to counteracting the deleterious effect of negative externalities - land pollution, cutting of trees without replanting, overgrazing and overcultivation (which are apparent in the area from visual observation through site visits). An effective tourism strategy ought to integrate socioeconomic, technical and environmental factors linked to community livelihood improvement in the study area.

\section{Conclusions}

The study showed that the Musina Municipality offers an abundance of sustainable ecotourism potential. This potential derives from a range of natural resource assets and factor endowments in the study area. While Ramaano (2019) correctly identified local ecotouristic potential as encompassing agricultural sites, arts and crafts, significant indigenous plants and tree species, fauna, as well as heritage legacy resources, this study specifically suggests that tree species (marula and baobab) are among the main potential touristic attractions in the area. Apart from ecotourism, ethnobotanicals within the area of conservancies hold prospect as being viable sources of new product development that could sustain medical tourism and, in collaboration with international pharmaceutical companies, could even be exported. To these potentials, beyond agro- and medical tourism, can be added adventure, cultural and heritage tourism - the "optimal" mix to be determined through future research on the subject matter. Figure 4 illustrates the principles of sustainable tourism that ecotourism banks on. Meanwhile, Figure 5

Figure 4 .

The sustainable tourism principles and framework

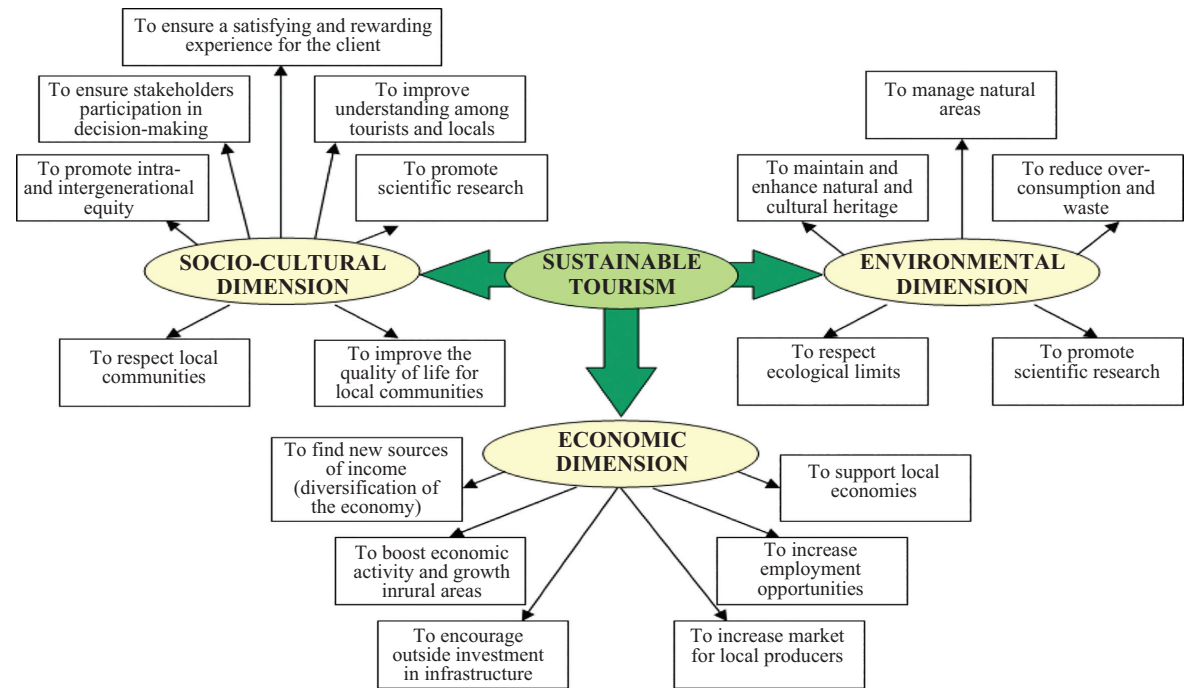

Source(s): White et al. (2006), Zamfir et al. (2017), Ramaano et al. (2021) 


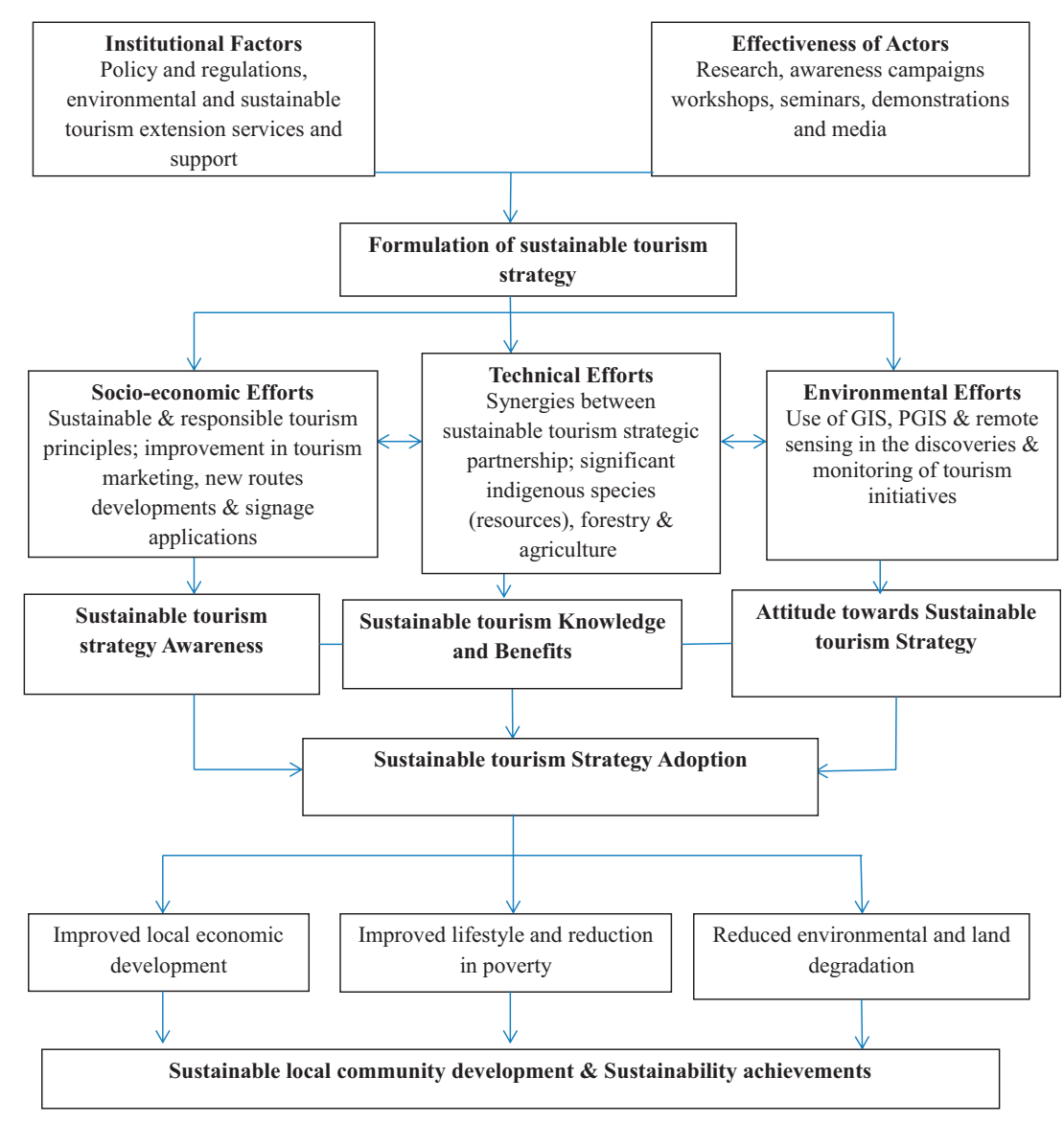

Source(s): Author's own; Ramaano, 2019, 2021
Mechanism to buoy community livelihoods

Figure 5.

The recommended envisaged effective sustainable tourism strategy and model of the study

depicts the ideated theme of sustainable tourism and livelihoods development in the study area.

\section{Notes}

1. Indeed, as early as the 1998 Job Summit in South Africa, the tourism sector was showcased as a mechanism to curb unemployment, generate income and alleviate poverty in rural areas. The White Paper on the development and promotion of tourism in South Africa not only deems the tourism sector as a national priority, but it also asserts that tourism has to be advanced in a mode that leads to better life quality for every South African (South Africa, 1996; DEAT, 2000a, b; Keyser, 2002).

2. Ecotourism can improve permaculture and horticulture by providing secondary and alternative revenues (Ramaano, 2019). Specifically, farm tourism (agro-tourism) developments may elevate the standard of living of rural residents (Ramaano, 2021). Agronomy and agro-industrial education are significant dimensions in promoting and boosting agricultural production. Aligning education with vocational skills needed to undertake enterprises and initiatives involving a medley of agro-, cultural and sustainable tourism in rural milieus, such as in the current study area, should be prioritized by national, regional and local authorities. 


\section{JBSED 1,1}

3. Any endeavor designed to amalgamate biological resources with linked indigenous knowledge for economic exploitation. It is also known as biodiversity prospecting. Bioprospecting, in conjunction with partnerships and agreements with external actors, can be a fundamental part of medical tourism in the rural communities that dwell next to the protected areas. For example, pharmaceutical products derived from ethnobotanicals within the areas of conservancies can be produced in conjunction with knowledge inputs from international pharmaceutical companies.

4. Situated between $22^{\prime} 25^{\prime} 00^{\prime \prime}$ and $22^{\circ} 50^{\prime} 00^{\prime \prime} \mathrm{E}$ lines of latitude and between $30^{\circ} 20^{\prime} 15^{\prime \prime}$ and $31^{\circ} 01^{\prime} 22^{\prime \prime} \mathrm{S}$ lines of longitudes. See (Figure 1) for the location map (Musina municipality, 2017, 2019; Ramaano, 2019, 2021).

5. Among other locales, biodiversity abounds within the Mukununde and Makavhini Mountains (Ramaano, 2019). Other centers of ecotouristic potentials in the study area are within the Big Tree [Baobabs] Nature Reserve, [Dambale Bushmen Rock Paintings], [Sagole Spa], [Musina tourism info and hub] and [Tshipise forever resort]. The previously mentioned melds heritage and cultural potential with ecotourism. Adoption of sustainable touristic development initiatives, in juxtaposition with cultural and heritage elements, provides, cognate with ecotourism, to drive sustainability of socioeconomic development in local rural areas.

6. A purposive sample is a nonprobability sample. It is selected based on population features and the aim of the study. The reason for nominating this kind of sampling was that the researcher believed that he could obtain a representative sample by using the reasonable mind, which would ensue in conserving time and money (Patton, 2001; Ramaano, 2019, 2021).

7. Distinguished informants had varied preferences for meeting times; some chose morning sessions while others went for afternoon slots as per earlier arrangements. Also, distance nature influenced research sessions. Concerning the entire investigation process, closer areas got morning slots, while afternoons were for too distant ones. In this way, a variety of data was gleaned from both local communities and adjacent tourism ventures.

8. Questionnaire survey within the four sampled villages distributed between the morning of March 1 and afternoon April 30 and collected between the morning of May 15 and afternoon of June 15, 2019.

9. Garnered from survey questionnaires distributed between the morning of March 1 and afternoon of April 30 and collected between the morning of May 15 and afternoon of June 15, 2019.

10. $90 \%$ of respondents from focus group discussions shared the same sentiments on the mentioned (Focus group discussions within all the sampled villages [mornings and afternoons] March 17/18/ 19/20, 2019).

11. Questionnaire survey within the four sampled villages distributed between the morning of March 1 and afternoon of April 30 and collected between the morning of May 15 and afternoon of June 15,2019 .

12. Focus group discussions within all the sampled villages [mornings and afternoons] March 17/18/19/ 20, 2019 .

13. Key informant interviews $(n=30)$ within the six sampled tourism ventures and entities April 8/9/10, 2019 during the mornings and afternoons.

14. Questionnaire survey within the four sampled villages distributed between the morning of March 1 and afternoon April 30 and collected between the morning of May 15 and afternoon of June 15, 2019.

15. Focus group discussions within all the sampled villages [mornings and afternoons] March 17/18/19/ 20, 2019.

16. Questionnaire survey within the four sampled villages distributed between the morning of March 1 and afternoon of April 30 and collected between the morning of May 15 and afternoon June 15, 2019.

17. For example, Baobab [Adansonia], Marula [Sclerocarya birrea] or Mopani [Colophospermum mopane]. Trees such as marula attract domestic tourists for gathering and drinking traditional beer made from marula fruits. The latter enables local income generation from domestic tourists from buying the beer. Other significant species such as baobabs [Adansonia digitata] have various 
significant values ranging from the selling of their fruits to the production of oil and juice from their fruits and seeds, as well as contents from their bark.

18. Focus group $(n=20)$ within all the sampled villages [mornings and afternoons] March 17/18/19/ 20, 2019.

19. Maikhuri et al. (2007) recommended value addition in inherent wild edibles of central Himalaya for sustainable livelihood and small-scale enterprise development.

20. Fuel wood is the prime energy source for residential destinations in the developing world in rural and city contexts (Madubansi and Shackleton, 2007). In most rural areas, it is from the notable Mopani trees [Colophospermum mopane].

21. Questionnaire survey within the four sampled villages distributed between the morning of March 1 and afternoon of April 30 and collected between the morning of May 15 and afternoon of June $15,2019$.

22. Focus group $(n=20)$ within all the sampled villages [mornings and afternoons] March 17/18/19/ 20, 2019.

23. Key informant interviews $(n=30)$ within the six sampled tourism ventures and entities April 8/9/ 10, 2019.

24. Solely the respondents from LED (Local Economic Development) and tourism info center (Musina municipal offices).

\section{References}

Acha-Anyi, P.N. (2014), Developing a Sustainable Community Tourism Strategy for Townships: The Case of Soshanguve, (Doctoral dissertation), North-West University, Potchefstroom.

Ashley, C. (2002), "Methodology for pro-poor tourism case studies", PPT Working Paper No. 10, Overseas Development Institute, available at: http://www.propoortourism.org.uk/10_methodology. pdf.

Ashley, C., Boyd, C. and Goodwin, H. (2000), Pro-poor Tourism: Putting Poverty at the Heart of the Tourism Agenda, DFID, London.

Banskota, K. and Sherma, B. (1996), Tourism for Mountain Community Development: Case Study Report on the Annapurna and Gorkha Regions of Nepal, International Centre for Integrated Mountain Development (ICIMOD), Centre for Environment and Resource Studies (Crest), Kathmandu.

Chok, S., Macbeth, J. and Warren, C. (2007), "Tourism as a tool for poverty alleviation: a critical analysis of 'pro-poor tourism' and implications for sustainability", Current Issues in Tourism, Vol. 10 Nos 2-3, pp. 144-165.

De Haan, A. (1999), "Livelihoods and poverty: the role of migration-a critical review of the migration literature", Journal of Development Studies, Vol. 36 No. 2, pp. 1-47.

Department of Environmental Affairs and Tourism (DEAT) (2000a), Transforming the South African Tourism Industry, Unpublished paper, DEAT, Pretoria.

Department of Environmental Affairs and Tourism (DEAT) (2000b), Unblocking Delivery on Tourism Strategy by Governmental Departments, Pretoria, p. 2.

Department of Environmental Affairs and Tourism (DEAT) (2003), Principles and Guidelines of Community Based Natural Resource Management, DEAT, Pretoria.

Dieke, P.U.C. (2001), Kenya and South Africa, The Encyclopedia of Ecotourism CABI Publishing, Wallingford, pp. 89-106.

Eagles, P.F.J. and McCool, S.F. (2002), Tourism in National Parks and Protected Areas: Planning and Management, CABI Publishing, Wallingford, p. 320.

Ekanyake, E.M. and Long, A.E. (2012), "Tourism development and economic growth in developing countries", The International Journal of Business and Finance Research, Vol. 6 No. 1, pp. 51-63.

Mechanism to buoy community livelihoods

\section{$+$}


JBSED 1,1

Eshun, G. (2014), "Towards the dual mandate of ecotourism in Africa-comparative evidence from Ghana”, Africa Insight, Vol. 44 No. 3, pp. 164-184.

Ferreira, S. (2004), "Problems associated with tourism development in Southern Africa: the case of transfrontier conservation areas", Geo Journal, Vol. 60 No. 3, pp. 301-310.

Goodwin, H. (2002), "Local community involvement in tourism around national parks: opportunities and constraints", Current Issues in Tourism, Vol. 5 Nos 3 and 4, available at: http://www. multilingual-matters.net/cit/005/0338/cit0050338.pdf.

Goodwin, H. (2008), “Tourism, local economic development, and poverty reduction”, Applied Research in Economic Development, Vol. 5 No. 3, pp. 55-64.

Govender-Van Wyk, S. (2007), Community-Based Sustainable Tourism on Commonages: An Alternative to Traditional Land Reform in Namaqualand, Northern Cape Province, University of Pretoria, Hatfield.

Jamal, T. and Stronza, A. (2009), "Collaboration theory and tourism practice in protected areas: stakeholders, structuring and sustainability", Journal of Sustainable Tourism, Vol. 17 No. 2, pp. 169-189.

Lanjouw, P. and Ravallion, M. (1995), "Poverty and household size", The Economic Journal, Vol. 105 No. 433, pp. 1415-1434.

Keyser, H. (2002), Tourism Development, University Press, Southern Africa (Pty), OxfordCape Town.

Kirsten and Rogerson (2002), Ecotourism development: Development Southern Africa Journal, Vol. 22 No. 1.

Liu, W., Vogt, C.A., Luo, J., He, G., Frank, K.A. and Liu, J. (2012), "Drivers and socioeconomic impacts of tourism participation in protected areas", PLoS One, Vol. 7 No. 4, p. e35420, doi: 10.1371/ journal.pone.0035420.

Madubansi, M. and Shackleton, C.M. (2007), "Changes in fuel wood use and selection following electrification in the Bushbuckridge Lowveld, South Africa", Journal of Environmental Management, Vol. 83 No. 4, pp. 416-426.

Maikhuri, R.K., Negi, V., Rawat, L.S. and Purohit, V.K. (2007), Promoting Value Addition in Potential Wild Edibles of Central Himalaya for Sustainable Livelihood and Small Scale Enterprise Development, GB Pant Institute of Himalayan Environment and Development.

Maxwell, S. (2001), The Evolution of Thinking about Food Security, ITDG Publishing, London.

May, J. (1998), Poverty and Inequality in South Africa, Report Prepared for the Office of the Executive Deputy President and the Interministerial Committee for Poverty and Inequality, Deputy President's Office, Pretoria.

Mbaiwa, J.E. (2015), “Ecotourism in Botswana: 30 years later”, Journal of Ecotourism, Vol. 14 Nos 2-3, pp. 204-222.

Mitchell, J. and Ashley, C. (2010), "Tourism and poverty reduction: pathways to prosperity", Tourism, Environment and Development, Earthscan, London.

Mugizi, F., Ayorekire, J. and Obua, J. (2017), "Factors that influence local community participation in tourism in murchison falls conservation area", Journal of Environmental Science and Engineering, Vol. A6 No. 2017, pp. 209-223.

Musina Municipality (2007), Integrated Development Plan, Limpopo.

Musina Municipality (2017), Integrated Development Plan, Limpopo.

Musina Municipality (2019), Integrated Development Plan, Limpopo.

Nheta, D.S. (2017), Profiling Ecotourists within the Capricon District Municipality, (Masters Dissertation), University of Venda, Limpopo.

Patton, M.Q. (2001), Qualitative Research and Evaluation Methods, 2nd ed., Sage Publications, Thousand Oaks, CA. 
Poto, S.T. and Mashela, P.W. (2008), "Baseline determination of habitat for indigenous medicinal plants in the sekhukhune and Vhembe District of Limpopo Province", Proceedings 63 of International Climate Change Conference, 21 October 2008, Oasis Lodge.

Ramaano, A.I. (2019), The Prospects of Using Tourism Industry to Advance Community Livelihoods in Musina Municipality, University of Venda, Limpopo.

Ramaano, A.I. (2021), Tourism Policy and Environmental Impacts in Musina Municipality: Lessons from a Case Study of Failure, Tourism Critiques: Practice and Theory.

Ryan, C. (2001), "Tourism in the South Pacific — a case of marginalities", Tourism Recreation Research, Vol. 26 No. 3, pp. 43-49.

Ryan, C. and Page, S. (Eds) (2012), Tourism Management, Routledge.

Scheyvens, R. (1999), "Ecotourism and the empowerment of local communities", Tourism Management, Vol. 20 No. 2, pp. 245-249.

Scheyvens, R. (2007), "Exploring the tourism poverty nexus", Current Issues in Tourism, Vol. 10 Nos 2-3, pp. 231-254.

Shackleton, C.M., Shackleton, S.E., Buiten, E. and Bird, N. (2007), "The importance of dry woodlands and forests in rural livelihoods and poverty alleviation in South Africa", Forest Policy and Economics, Vol. 9 No. 5, pp. 558-577.

Snyman, S. (2017), "The role of private sector ecotourism in local socio-economic development in southern Africa", Journal of Ecotourism, Vol. 16 No. 3, pp. 247-268.

South Africa (1996), White Paper on the Development and Promotion of Tourism in South Africa, Department of Environmental Affairs and Tourism, Pretoria.

South Africa (2000), Integrated Sustainable Rural Development Strategy, Deputy President's Office, Pretoria.

Spenceley, A. (2008), Responsible Tourism: Critical Issues for Conservation and Development, Earth scan, London.

UNEP (2016), Protected Planet Report 2016: How Protected Areas Contribute to Achieving Global Targets for Biodiversity, World Conservation Monitoring Centre, Cambridge.

White, V., McCrum, G., Blackstock, K.L. and Scott, A. (2006), Indicators and Sustainable Tourism: Literature Review, The Macaulay Institute. Aberdeen.

Yamane, T. (1973), Statistics: An Introductory Analysis, Harper and Row, New York, NY.

Zamfir, A., Popa, I., Cicea, C., Dobrin, C. and Marinescu, C. (2017), New Experiences for International University Cooperation in Economic Education and Research in Romania, The Bucharest University of Economic Studies, pp. 1392-1400, doi: 21125/inted.2017.0468.

Zhao, W. and Ritchie, J.R.B. (2007), "Tourism and poverty alleviation: an integrative research framework", in Hall, C.M. (Ed.), Pro Poor Tourism; Who Benefits? Perspectives on Tourism and Poverty Reduction, Channel View Publications Clevedon.

\section{Further reading}

Cobbinah, P.B., Black, R. and Thwaites, R. (2013), "Tourism planning in developing countries: review of concepts and sustainability issues", International Journal of Social, Human Science and Engineering, Vol. 7 No. 4, pp. 313-320.

De Azeredo Grünewald, R. (2002), "Tourism and cultural revival”, Annals of Tourism Research, Vol. 29 No. 4, pp. 1004-1021.

Dwyer, L., Forsyth, P. and Dwyer, W. (2010), Tourism Economics and Policy, View Publications, Ottawa.

Esterberg, K.G. (2002), Qualitative Method in Social Research, McGraw-Hill, Boston.

Gössling, S., Peeters, P., Ceron, J.P., Dubois, G., Patterson, T. and Richardson, R.B. (2005), "The ecoefficiency of tourism", Ecological Economics, Vol. 54 No. 4, pp. 417-434.
Mechanism to buoy community livelihoods 
JBSED 1,1
Hall, C.M., Gössling, S. and Scott, D. (2015), “Tourism and sustainability”, The Routledge Handbook of Tourism and Sustainability, p. 1.

Liu, Z. (2003), "Sustainable tourism development: a critique", Journal of Sustainable Tourism, Vol. 11 No. 6, pp. 459-475.

Moscardo, G. and Murphy, L. (2014), "There is no such thing as sustainable tourism: Reconceptualizing tourism as a tool for sustainability”, Sustainability, Vol. 6 No. 5, pp. 2538-2561.

Moulin, C. and Boniface, P. (2001), "Routeing Heritage for Tourism: making heritage and cultural tourism networks for socio-economic development", International Journal of Heritage Studies, Vol. 7 No. 3, pp. 237-248.

Mowforth, M. and Munt, I. (2016), Tourism and Sustainability, Development Globalisation and New Tourism in the Third World, Routledge Publishers.

OECD (Organization for Economic Cooperation and Development) (2010), Tourism Trends and Policies 2010, OECD, Paris.

Pandey, D.N., Gupta, A.K. and Anderson, D.M. (2003), "Rainwater harvesting as an adaptation to climate change", Current Science, Vol. 85 No. 1, pp. 46-59.

Tao, T.C.H. (2006), Tourism as a Livelihood Strategy in Indigenous Communities: Case Studies from Taiwan.

Timothy, D.J. (1998), "Cooperative tourism planning in a developing destination", Journal of Sustainable Tourism, Vol. 6 No. 1, pp. 52-68.

UNECA (United Nations Economic Commission for Africa) (2010), Governing Development in Africathe Role of the State in Economic Transformation, UNECA, Addis Ababa.

United Nations World Tourism Organization (2002), Enhancing the Economic Benefits of Tourism for Local Communities and Poverty Alleviation, UNWTO, Madrid.

World Bank (2011), Annual Report, World Bank, Washington DC.

\section{Corresponding author}

Azwindini Isaac Ramaano can be contacted at: azwira@webmail.co.za

For instructions on how to order reprints of this article, please visit our website:

www.emeraldgrouppublishing.com/licensing/reprints.htm

Or contact us for further details: permissions@emeraldinsight.com 